\title{
Analysis of Performance-Based Budgeting System Implementation in Improving Organizational Effectiveness
}

\author{
Liwaul, Rosika, Hj. Ninik Endang Purwati, Hamryati \\ Universitas Halu Ole, Southeast Sulawesi, Indonesia
}

\begin{abstract}
This study aimed to: 1) investigate and analyze the implementation of performance-based budgeting system in the Regional Secretariat of Wakatobi District: 2) analyze the organizational effectiveness in the Regional Secretariat of Wakatobi District.

Object of the study was the Regional Secretariat of Wakatobi District. Population of the study was all staff at the Regional Secretariat of Wakatobi regency. Informants are determined through purposive sampling method using the following criteria: 1) knowing about the policy of involvement in performance of performance-based budgeting; 2) knowing about the policy of performance-based budgeting; 3) directly involved in the implementation of performance-based budgeting. Data were collected using interview and documentation methods. Data from the research were analyzed descriptively and qualitatively.

Results infected that: 1) the application of performance-based budgeting in the Regional Secretariat of Wakatobi District has been done in consistently in accordance with the central government's rules and the Ministry of Finance's regulation, which encompasses everything from determining vision and mission, determining programs and activities, Formulating performance indicators, determining cost standards, activity spending, and making reports; 2) the performance achievement in the Regional Secretariat of Wakatobi District has been very effective.
\end{abstract}

Keywords - performance-based budgeting system, organizational effectiveness

\section{INTRODUCTION}

One of the reform agenda in the Indonesian government system that started in 1998 was the improvement of governance and management of state budget which was previously considered not maximal in realizing the welfare for all the people. Fundamental changes in the budget management system in Indonesia begin with the birth of Law No. 17 of 2003 on State finances. One of the key points in this law is the change in the budgeting system, from traditional budgeting systems to performance-based budgeting systems. The fundamental differences between traditional budgeting systems and performance-based budgeting systems include the following: 1) traditional budgeting systems only prioritize administrative completeness in reporting budgetary usage, while performance-based budgets, budget accountability reports in addition to administrative completeness, the most important is the results achieved or Performance demonstrated in terms of performance, inputs, processes, outputs and the benefits and impacts of any use of the state budget;2) In the traditional budgeting system, the success of budget execution is measured by the ability to realize the amount of budget each year from the nominal specified in the planning, while in performance-based budgeting, the success in budget management is measured by the ability to realize the performance targets in the priority program planning specified annually in Order to realize the vision and mission of the government every five years.

Determination of performance based budgeting policy as stated in Law No. 17 of 2003 on State finances, to accommodate best practices (best practices) internationally. Best practices in question include the establishment of a results-oriented accountability principle or often referred to as the accountability of performance (performance accountability) and transparency in the management of state finances. Implementation of performance-based budgeting as stipulated in this law in line with the budget implementation of the integrated (unified budget) that emphasize the optimization of the use of funds to achieve program objectives; and the medium term expenditure framework (medium term expenditure framework), in order to improve discipline and budget allocations are efficient with an estimated forward (forward estimates), as a basis for changing policies, programs, and activities from time to time, allocating resources and determining With better priorities and important government goals.

Implementation of performance-based budgeting is expected to change the performance appraisal paradigm of agencies / work units in the past more based on the amount of funds absorbed from a program / activity, into an assessment based on the achievement of performance as measured by substantive indicators generated a program / activity Copyright (C) 2011 Unikom Center Implemented efficiently, effectively, economically, and in line with the policy and mission and vision of the organization. 
Regional Secretariat of Wakatobi District, is one of the entities of local government institutions that are required to implement and realize the implementation of performance-based budget in the management of programs and activities set out in the organization. Performance-based budgeting, in addition to streamlining the use of resources related to public services and development implementation, is also intended to streamline organizational management. In this context, the implementation of performance-based budgeting in the Regional Secretariat of Wakatobi District is expected to increase the effectiveness of the organization in running the government, development and public services which are the main tasks and functions.

The implementation of performance-based budgeting system at Regional Secretariat of Wakatobi District started to be applied. It is marked by the existence of program planning documents and budget accompanied by clear performance targets, the information about the objectives and targets to be achieved through measured activities and programs in accordance with the targets and indicators set by taking into account the availability of existing budget, On the achievement of the performance of every use of the budget and reporting performance accountability for the programs and activities that have been implemented every fiscal year.

Things have not done consistently in terms of performance-based budgeting is the start of the performance appraisal process, out put, the benefits and impact of the use of the budget each year. Because the budgeting performance appraisal has not been done consistently and continuously, then there is the impression of organizational management has not been effective. One manifestation of the ineffectiveness of organizational management is that there are still many programs and activities conducted repeatedly from year to year, with the results not yet able to reach $100 \%$ of the planned targets. Some of the targets that have not yet been realized are: 1) Number of Pre-Draft Perda / Pebup job description / job description (document) that is only $80 \%$ of the target set; 2) Pre-Authority Plan (document) is only 75, 71\% of the target is still in good category; 3) Maintenance of House of Position is only $80 \%$ that can be realized; 4) Maintained Office Building only reaches $80 \%$, Mobil Officers are kept only $70 \%$ and Official Service / Vehicle maintained only $75 \%$ of the target set. An interesting question to examine further is whether this is a consequence of implementing a performance-based budgeting system, in which SKPD finds it difficult to formulate new performance targets so that it tends to do repetition in setting performance targets implemented every year?.

\section{LITERATURE REVIEW}

\section{Concept of performance-based budgeting}

Budgeting is a financial plan that systematically shows the allocation of human resources, materials, and others resources. Various variations in the government budgeting system were developed To serve a variety of purposes including for financial control, plans Management, priority of use of funds and accountability to Public (Mohamad, 2006). In general budgeting (budgeting) is a way / systematic method for allocating resources, especially financial resources. In its development, the budgeting system is required to be more responsive and able to facilitate the fulfillment of demands on improving the quality of public services and resource efficiency through improved performance oriented to outcomes, benefits and impact.

A budget is a statement about the estimated performance to be achieved over a given period of time expressed in financial size, whereas budgeting is the process or method for preparing a budget. In public sector organizations in general, budgeting is a political process. In general, budgeting is related to the process of determining the amount of fund allocation for each program and activity in a monetary. This budgeting process begins when strategy formulation and strategic planning are completed. Budget is the articulation of strategy formulation and strategic planning that has been made. Budgetary stage is very important, because the budget is not effective and not performance oriented will be able to thwart the plan that has been prepared. Budget is a managerial plan to take action (managerial plan for action) in order to facilitate the achievement of organizational goals.

The legal basis for performance-based budgeting in Indonesia is Law no. 17 Year 2003 on State Finance which is an important milestone of the updating of the budgeting system. In accordance with Article 3 paragraph 2 of Government Regulation no. 20 of 2004, the State Ministry or State Institution is obliged to develop programs and activities based on performance. A budget with performance approach is a budget system that promotes the achievement of work results or output of the cost allocation plan or the specified input (Explanation of Regulation No. 105 of 2000, Article 8). To formulate a performance-based budget, the State Ministry / Institution must first have strategic planning (Renstra). The substance of the Strategic Plan provides a picture of where the organization should be heading and how (strategies) to achieve that goal.

Financial Permen No 93 / PMK.02 / 2011 /PMK.02/ 2010 on guidance on the preparation and review of work plans and budgets of ministries of State or Institution explained that the preparation of budget in the Work Plan and Budget document of State Ministry / Institution (RKA-K / L) Is part of the preparation of the State Budget (APBN). The preparation of the APBN includes the preparation of RKA K / L documents including the State General Treasurer's Spending Fund (RDP- State Treasurer). Due to differences in the drafting procedure 
between State Ministry / Institution (K / L) budget and State General Treasurer budget (BUN), the budget document in Attachment to this Regulation of Minister of Finance shall be divided into: 1) RKA K / L is document The annual financial plan of $\mathrm{K} / \mathrm{L}$ compiled according to the Budget Section of the Ministry / Agency; 2) RDP of State General Treasurer shall be the work plan and budget of the State General Treasurer's Budget Section detailing the funding needs in the form of expenditure and financing in order to fulfill the obligations of the Central Government and transfers to regions whose management is authorized by the President to the Minister of Finance as State Treasurer .

Integrated budgeting is done by integrating all planning and budgeting processes within the $\mathrm{K} / \mathrm{L}$ environment to produce RKA K / L documents by budget classification according to organization, function, and type of expenditure. Integration or integration of planning and budgeting process is intended to avoid duplication in the provision of funds for $\mathrm{K} / \mathrm{L}$ either investment or operational costs.

Performance-based budgeting aims to improve the efficiency and effectiveness of public expenditure by linking the funding of public sector organizations to the results they deliver, making systematic use of performance information. There are a number of models of performance-based budgeting that use different mechanisms to link funding to results. Some have very sophisticated features and require the support of correspondingly sophisticated public management systems (see below), while others focus more on the basics. Performance-based budgeting should not be seen as an isolated initiative. It should be viewed, rather, as part of a set of broader reforms - often referred to as managing-for-results - designed to focus public management more on results delivered and less on internal processes. These broader reforms include civil service reforms designed to increase the motivation and incentives of public employees; organizational restructuring to increase the focus on service delivery and improve coordination (e.g., creation of agencies and reduction of the number of ministries); and institutional and oversight changes to strengthen public accountability for performance. Action on these and a range of related fronts is necessary if the efficiency and effectiveness of public expenditure is to be substantially improved.

\section{Organizational effectiveness}

According to Devas, et al. (1989) is the effectiveness of the relationship between the output and the destination or can also be said is a measure of how far the level of output, policies and procedures of the organization. Effectiveness is also related to the degree of success of an operation in the public sector so that an activity is said to be effective if the activity has a major influence on the ability to provide community service which is a predetermined target. Furthermore, Devas, et al (1989: 279-280) argues that the outcomes of government activities in managing regional finances should be such as to enable programs to be planned and implemented to achieve government goals at the lowest possible cost and in the shortest possible time. That is the measure of effectiveness in organizational savings associated with budgeting.

Komaruddin (1994: 294) argued that effectiveness is a state that shows the level of success of management activities in achieving the goals that have been set first. In view of the organization as a system, efforts to discuss organizational effectiveness more comprehensively become more likely. In reality it is very difficult to see or equate organizational effectiveness with the level of success in achieving goals. This is due to the fact that there is always an adjustment in the target to be achieved, also in the process of achieving it often there is pressure from the surrounding circumstances. This fact subsequently causes that rarely can the target be achieved as a whole.

Effectiveness is the relation between output and purpose. In the sense of effectiveness is a measure of how far the level of output, policies and procedures of the organization to achieve the goals set. In the theoretical or practical sense, there is no universal agreement on what is meant by "effectiveness". However the definition of effectiveness is related to the general approach. When explored the effectiveness comes from the basic word effective which means: 1) There are effects (influence, consequence, impression) such as: efficacious: efficacious: impervious; 2) The use of methods, means, means or tools in carrying out the activities so as to be effective (achieving optimal results). 
III. CONCEPTUAL FRAMEWORK

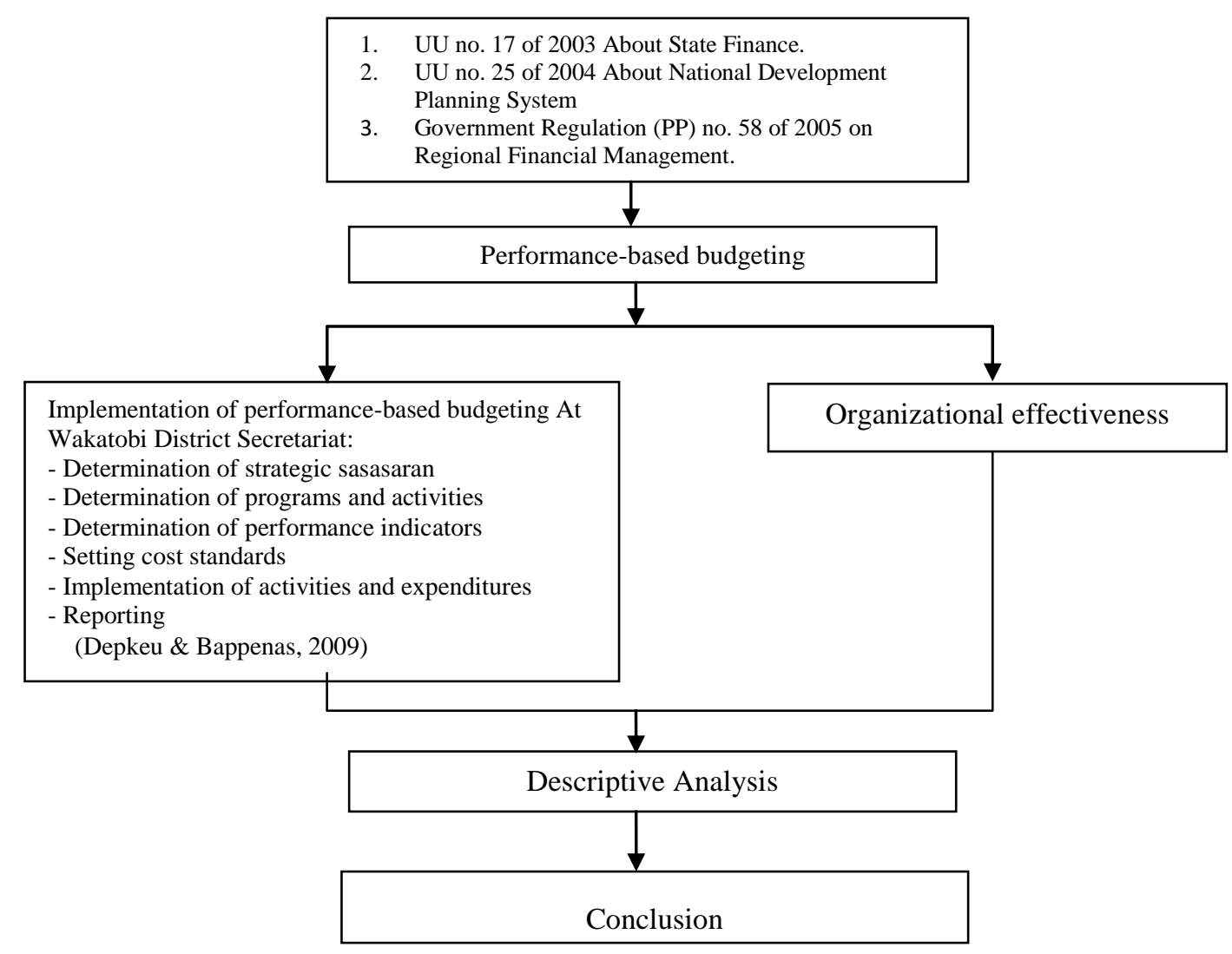

\section{Object of Research}

IV. RESEARCH METHOD

The object of this research is the Regional Secretariat of Wakatobi District, with the consideration that Wakatobi District is an autonomous region of the regency of Buton District. Besides, the Regional Secretariat of Wakatobi District is the assistant element of the Regional Government who has the task of assisting the Regional Head in the administration, administration, and provide administrative services to all regional devices in Wakatobi District.

\section{Research design}

This study used qualitative design, relying on statistical data and expression as a basis in conducting the discussion and describe of findings in the study. Qualitative design is used because the context of this study is a study that examines performance-based budgeting systems. Such a study is more appropriate when approached with a qualitative approach. As Bogdan and Biglen (1982: 30) argue that the underlying qualitative research is; (1) the researcher as the main instrument of research to come directly on the data source; (2) data collected by researchers in the form of words instead of numbers; (3) the results of qualitative research put more emphasis on process not on result;(4) through inductive analysis, the researcher will reveal the meaning of the observed state according to the situation / situation with what is in the field.

\section{Study Focus and Aspects Observed}

This study will examine the implementation of the program with the main focus is to answer the questions as formulated in the problem. Therefore, the focus of the study is to describe and analyze the process and stages of implementation of performance-based budgeting in the District Secretariat of Wakatobi District which consists of: 1) determination of strategic sustainability, 2) determination of programs and activities, 3) determination of performance indicators, 4) standard cost setting, 5 ) Implementation of activities and expenditures, 6) reporting. Besides, this study also observed the level of effectiveness performance Regional Secretariat of Wakatobi Regency. 


\section{Informant Research}

The research informants are those who represent the elements mentioned such as elements of leadership, budget management staff. Determination of informants is done purposively with consideration: 1) the person represents the elements involved in the implementation of performance-based budgeting; 2) knowing performance based budgeting policies; 3) are directly involved in the implementation of performance-based budgeting.

\section{Data collection technique}

Data collection in this research is done based on the type of research and the type of data needed in accordance with the formulation of the problem. Given that this research is a qualitative research then to complete the materials in the form of data required in the discussion of the results of this study, the researchers conducted a series of activities of collecting data and relevant information. Starting from the exposure of aspects of research that the researcher wants to analyze, the data collection techniques required in this study is to use techniques / methods of data collection ie; (1) documentation study in the form of performance report of Setda Wakatobi, (2) in-depth interview, (3) observation.

The use of these three techniques to assist researchers in the activities of collecting the necessary data, can be explained as follows:

\section{Documentation Study}

Activities of data collection and information needed as material in supporting the results of this study, also attempted through the way of reviewing documents created by the setda Kab. Wakatobi or other documents related to preparation, execution, and assessment of performance-based budgeting systems in improving organizational effectiveness. Documentation studies conducted by researchers are to collect data through the way of recording and collecting data in the form of relevant documents.

2. Interview

Interview method in doing research is semi-structured interview (semi structure interview), which, according to Hadi (2004: 217) is a kind of interview that is included in the category of in-depth interviews or in-depth interviews, which in practice is more free than a structured interview. The purpose of this type of interview is to open the issue more openly, in which the party in the interview was asked his opinion about the implementation of performance based budgeting system in improving organizational effectiveness in the Regional Secretariat of Wakatobi Regency.

3. Observation

Researchers conduct passive participation observation, because researchers only intend to reveal descriptive description of the implementation of performance based budgeting policy management without participating actively in it. Researchers only act or act as a single observer by listening to information from the informant then doing the observation.

\section{Data analysis technique}

Data analysis technique used in this research is descriptive-qualitative analysis technique based on reality obtained in the field. Research with this technique seeks to disclose, then describe and then present and interpret data from the field according to each component that is evaluated as it is without controlling. (Sugiyono, 2006: 3) is seen as an attempt by researchers in analyzing qualitative data by working by organizing data, choosing them into manageable units, synthesizing them, finding and finding patterns, finding what is important to analyze, and deciding what That can be told to others.

Data analysis techniques will be performed in accordance with qualitative research data analysis techniques whose stages are as follows:

1. Complete data collection of both written data (secondary) as well as voice data from cassette recordings, as well as official photographs;

2. Conducting transcripts of interview results, from voice data to written data;

3. Sorting or selection (sorting) data in accordance with the needs in answering research problems; And grouping or codifying data according to the type of information required;

4. Create or compile statement quotes informants in accordance with the needs in data presentation.

5. Formulate final data, present, analyze, interpretation and give meaning and clarify findings in theory or concept referenced in this research. 


\section{RESULT AND DISCUSSION}

Budget Allocation of Regional Secretariat, Wakatobi District

\begin{tabular}{|c|c|c|}
\hline No & Mission & $\begin{array}{l}\text { Budget Allocation } \\
(\mathbf{R p})\end{array}$ \\
\hline 1 & $\begin{array}{l}\text { Improving coaching and utilization of local government apparatus } \\
\text { Professional, Neutral and Prosperous (PNS) }\end{array}$ & $1.542 .579 .000,-$ \\
\hline 2 & Promoting harmonized and responsive policy making; & $2.171 .711 .046,-$ \\
\hline 3 & Improving institutional and orderly administration of government; & $11.764 .685 .622,-$ \\
\hline 4 & $\begin{array}{l}\text { Improve regional competitiveness through transparent and } \\
\text { accountable financial and transparent management systems; }\end{array}$ & $1.309 .540 .545,-$ \\
\hline 5 & $\begin{array}{l}\text { Improving the coordination system and controlling the } \\
\text { implementation of governance and regional development. }\end{array}$ & $7.740 .138 .719,-$ \\
\hline & Total Budget & $24,528,654,932,-$ \\
\hline
\end{tabular}

Source: LAKIP Regional Secretariat of Wakatobi, 2013.

\section{Discussion}

Based on the formulation of research problems, the discussion in this study is the application of performance budgeting system based on the Regional Secretariat of Wakatobi District and the effectiveness of performance achievements Regional Secretariat of Wakatobi District.

\section{Implementation of Performance-Based Budgeting System}

The performance-based budgeting indicator in this study refers to the opinion of MOF \& Bappenas (2009): 1) determination of strategic sustainability, 2) determination of programs and activities, 3) determination of performance indicators, 4) setting cost standards, 5) implementation of activities and expenditures 6 ) Reporting.

\section{Formulation of Vision, Mission and Strategy}

The results showed that performance-based budgeting system is done through steps and stages including the formulation of vision, mission, strategy, and goals and objectives. Vision Regional Secretariat Wakatobi is "The bureaucracy that is effective and efficient". This vision statement contains two key words: bureaucracy and effective and efficient. Measuring the effectiveness of organizational management of the Regional Secretariat of Wakatobi Regency is the existence of an effective and efficient bureaucracy. Bureaucracy that will be developed is to create a local government organization that supports the policy of good governance (good governance) and excellent service. While the concept of effectiveness and efficiency intended in their vision is the realization of local government management that supports the improvement of work productivity through the utilization of resources economically.

The results support the idea Carter (1994 Young 2003) that the performance of the budget using the mission statement, goals and objectives to explain why the money is spent. Establishing these missions, goals and objectives is a way to allocate resources to achieve specific goals based on program objectives and measurable results.

\section{Program and Activity Determination}

Having determined the vision, mission, goals and objectives, then the next step undertaken by the Regional Secretariat of Wakatobi District is to arrange and establish programs / activities that can support the achievement of missions and vision set previously. The operational program in question is the process of determining or elaborating a policy in the framework of implementation of a plan. In line with the programs and activities in Renstra Regional Secretariat of Wakatobi District is stipulated as follows:

1. M contents I namely improving management and utilization of local government officials who are professional, neutral and prosperous (PNS). In practice, this first mission is translated into three (3) types of programs and 12 activities, the total nominal budget on the first mission of Rp. 1. 542. 579. 000, - .

2. M contents II, namely improving policymaking aligned and responsive to public concerns, $\mathrm{m}$ contents are translated into five (5) programs and 17 activities, the total nominal budget of the mission II Rp. 2. 171. 711. 046, - .

3. M contents III: increasing institutional and orderly development of public administration, the mission III translated into three programs and 27 activities, the total nominal budget on the third mission of Rp. 11. 764. 685. 622, - . 
4. M contents improve the competitiveness of the area through a system of financial management and local goods transparent and accountable, the contents IV $\mathrm{m}$ is translated into four programs with 8 activity, the total nominal budget on the fourth mission of Rp. 1. 309. 540. 545, -.

5. $\mathrm{M}$ contents improve the coordination and control system of governance and development, $\mathrm{V}$ mission is translated into 7 program with 17 activities, the total nominal budget on the fourth mission of Rp. 7,740,138,719, -

The total budget of the Regional Secretariat of Wakatobi District is Rp. 24.528.654.932, -. Determination of activities / programs to be implemented of course based on the description of the vision set by the Regional Secretariat of Wakatobi District, in addition to the consideration also is the urgency of activities and / or relevance to activities in previous years that have not been achieved.

The results of this study support the opinion of Paterson, William. \& Harahap, Gandhi (2010) that the performance-based budget structure follows a strict pattern relating to the administrative level of work units in the form of programs and activities. Programs consisting of a number of activities carried out by echelon 1 and echelon 2. While activities consist of a set of resources (in the form of personnel, goods including equipment and technology) used in activities to produce output in the form of goods and services.

The results of the study support the notion Robinson and Last (2009) that the budget program budgeting process should be based on a program that work unit must submit and present the budget in the form of programs supported by the cost and performance information.

\section{Determination of Key Performance Indicators}

The results of research related to key performance indicators for the Regional Secretariat of Wakatobi Regency refers to the programs and activities set previously. The determination of the performance indicators of each strategic objective is carried out with reference to the terms of a good and adequate performance indicator to measure the performance of government programs. Therefore, the determination of performance indicators explains about things, among others:

a. Relevance; Performance indicators should relate to what is measured and objectively can be used for decision making or conclusions about what measurable achievements are made;

b. Urgency or importance because it is a priority and should be useful to success, progress, or achievement (accomplishment).

c. Effectiveness and feasibility; Data / information relating to the relevant performance indicators can be collected, processed, and analyzed at reasonable cost.

The results support the opinion of Paterson, William. \& Harahap, Gandhi (2010) that programs and activities in performance-based budgets are presented through a series of key performance reflecting program performance superiority through efficiency and effectiveness measurement.

The results of the study support the notion Hou (2010) that the design of performance-based budgeting is based on the premise that incorporates performance measures in the budget will facilitate the monitoring of the program to see how well the government has reached the promised and desired outcomes.

\section{Setting the Cost Standards}

Each program and activities undertaken to achieve the vision and mission, as well as the goals and objectives of each activity, require a proportionate budget allocation. The ideal allocation of budget allocations should be based on the performance targets of each activity to be achieved in each program in accordance with the mission of the organization. In the case of the Wakatobi District Secretariat as described in LAKIP 2012, the budget allocation is defined according to the mission set.

The result of the research shows that the stipulation of standard cost to the activity / program of Regional Secretariat of Wakatobi District is done by taking into account several provisions such as: a) realization of budget performance of previous year, b) main performance indicator and Renstra, c) Rationalized by Government and DPRD in ceiling Temporary budget (PPAS).

Determination of the amount of budget allocation per SKPD was initially prepared by each SKPD, including also with the Regional Secretariat of Wakatobi District, and to determine the amount of cost per activity prepared by each SKPD, but the costing is done by the government together with DPRD in plenary session in DPRD .Activities that are financed certainly have a routine and non routine.

The cost standard is one of the instruments required in the preparation of the Local Government Budget Work Plan. Given the importance of cost standards for local governments, it is necessary to make improvements in the preparation, so that later the established cost standards can accommodate the needs of local governments in achieving the goals and targets set.

The results support the opinion of Paterson, William. \& Harahap, Gandhi (2010) that cost standards are applied as a means of measuring output costs, namely Standardized General Cost (SBU) standardized in State 
and Cross-regional Ministries and Special Cost Standards (SBK) is the average cost or unit cost for Ministries or Territories certain.

\section{Implementation of Activities and Expenditures}

The results showed that the process of budget execution related to the implementation of programs and activities established in the Regional Secretariat organization Wakatobi District carried out in accordance with existing regulations. The procurement process of goods and services has been conducted in accordance with the provisions of the procurement of goods and services. Various types of activities are carried out in accordance with the work program of the Regional Secretariat of Wakatobi District are generally divided into five types of activity, by its nature or by its objectives with indicators specifically that physical activity, procurement of goods, services and facilities, activities and study and study, the activities of human resource development apparatus and meeting activities / coordination, evaluation and monitoring.

Implementation of such activities carried out in order to realize the achievement of goals and objectives of each program that has been set. Technical implementation refers to the rules, is not done according to the organizer version.

The research result is in line with Government Regulation No. 58 of 2005 that the classification of expenditure by type of expenditure are: personnel expenditure, spending on goods and services, capital expenditures, interest, subsidies, grants, social assistance, expenditure for the results and financial assistance, and expenditure unpredictable. According to the Regulation No. 13 of 2006 expenditure by group consist of indirect and direct expenditure. Indirect expenditures are budgeted expenditure not directly related to the implementation of programs and activities. While budgeted direct expenditure is directly related to the implementation of programs and activities.

\section{Reporting}

The results showed that the Regional Secretariat Wakatobi make a report of activities in the form of Government Performance Accountability Report (LAKIP). Regional Secretariat LAKIP Wakatobi 2012 is an attempt to forward to: 1) To ensure relevance, compatibility and harmonization between planning, budgeting, and implementation of the program of activities of each fiscal year, particularly between sections within the Regional Secretariat Wakatobi; and 2) Ensure the achievement of budget and resources effectively and efficiently, and ensure the sustainability of the program over time.

The results showed that the successful management of the program and budget outlined in Government Performance Accountability Reports. Therefore, the preparation of Government Performance Accountability (LAKIP), based on planned performance. In the measurement of performance indicators of the budget, in addition to measure and determine the performance and results of a program / activity, it can also display the work or the performance of the government. The report becomes part of government accountability to the public or to the stakeholders. Reports on performance is also a means of communication with the stakeholders, in terms of explaining what was done, successes achieved, and the problems that occur in program implementation, The main programs or activities related to public money spent.

Government Institution Performance Accountability Report (LAKIP) Regional Secretariat Wakatobi achievement of 2012 contains various programs and activities as mandated by Act 32 of 2004 on Regional Government and is based on systematic writing as established by the State Administration Institute 29 Year 2010 Guideline of Determination of performance and Accountability Reporting Government performance.

The implementation of performance based budgeting system in the Secretariat Wakatobi performed consistently as set out in government regulatory and regulatory of finance minister, carried out from the determination of the vision and mission, formulating objectives and strategies, the establishment of programs and activities, the formulation of performance indicators, procurement activities, and reporting.

\section{Effectiveness of Performance Outcomes}

Upon analysis of the performance assessment of the achievements obtained that the achievement of performance targets based on indicators of achievement with a very good level of effectiveness, it implies that the Regional Secretariat Wakatobi district government has organized in accordance with the desired target both in the areas of coordination, policy formulation and administration. The performance achievements contained in the Government Performance Accountability Report (LAKIP) Regional Secretariat Wakatobi which is one of media accountability that inform the Regional Secretariat Wakatobi performance in governance and development in Fiscal Year 2012.

Regional Secretariat Wakatobi will take whatever action is necessary in accordance with the authority to enforce a governance across agencies can be implemented with the principles of good governance. and to further improve the achievement of performance targets in realizing the vision and mission of the Regional Secretariat of Wakatobi required consistency and commitment of the entire apparatus of the Regional Secretariat 
in improving the efficient use of resources optimally in accordance with the functions and benefits in order to obtain the achievements of better performance in the future, especially commitment in terms of improving the quality of human resources.

The results of this study support the notion Mardiasmo (2004) that so far, the only measure of performance that there is a performance measure defined by the central government, namely the rule that the number of regular expenses listed in the local budget is the maximum amount that can be spent for each postal expenditure routine. With this rule is called good performance routine expenses if its realization in accordance with the target, that is all routine expenditures of funds spent in the fiscal year concerned.

\section{Conclusion}

\section{CONCLUSION AND SUGgESTIONS}

Based on the analysis and discussion, it can put forward some conclusions as follows:

1. Implementation of performance-based budgeting system in Wakatobi done consistently Secretariat as set out in the government and regulatory finance minister carried out from the determination of the vision and mission, the establishment of programs and activities, the formulation of performance indicators, standardsetting costs, spending activities, as well as reporting.

2. The achievement of performance indicators at the Regional Secretariat of Wakatobi District with an excellent level of effectiveness. it implies that the Regional Secretariat Wakatobi district government has organized in accordance with the desired target both in the areas of coordination, policy formulation and administration.

\section{Suggestions}

1. Need to increase human resource or personnel budget administrator include all elements within the organization in order to understand the concept of performance-based budgeting so that its application can be realized comprehensively in the organization;

2. Need to increase commitment of officials in implementing performance-based budgeting, as the application of performance-based budgeting, the effectiveness of the organization in implementing the program and activities of the more measurable;

3. Further studies need to examine the implementation of the budget system relationship with effectiveness in managing organizational performance by using a quantitative approach to ensure relevance both aspects are observed in this study.

\section{REFERENCES}

[1] Anderson, James E, 1994. Public Policy Making - An Introduction (second edition), Texas A \& M University.

[2] Bastian, Indra, 2006. Sistem Perencanaan dan Penganggaran Pemerintahan Daerah di Indonesia, Salemba Empat, Jakarta. hal.38.

[3] BPKP, 2005. Pedoman Penyusunan Anggaran Berbasis Kinerja (Revisi). Jakarta.

[4] Departemen Keuangan Republik Indonesia \& Kementerian Negara Perencanaan Pembangunan Nasional / Badang Perencanaan Pembangunan Nasional (Bappenas). 2009. Buku Pedoman Penganggaran Berbasis Kinerja (PBK). Depkeu \& Bappenas, Jakarta.

[5] Dessler, Gary.1984. Manajemen Personalia. Terj.Agus Dharma,SH. Jakarta: Erlangga

[6] Devas, Nick.1989. Keuangan Pemerintah daerah di Indonesia. UI-Pres. Jakarta.

[7] Gibson, Ivancevich. 1984. Organisasi dan Manajemen Perilaku Struktur Proses. Jakarta: Penerbit Erlangga.

[8] Gibson, et al. 1996. Organisasi dan Manajemen, Edisi ke empat, Jakarta : Erlangga,

[9] Hadi, Sutrisno. 1993. Methodology Research, Yogyakarta : Fakultas Psikologi UGM.

[10] Hou, Yilin. 2010. The Performance of Performance-Based Budgeting in Boom and Bust Years: An Analytical Framework and Survey of States. Prepared for Presentation at the Annual Conference of the American Society for Public Administration (ASPA) San Jose, CA, April 9-13, 2010.

[11] Komarudin. 1994. Ensiklopedia Manajemen. Jakarta: Bumi Aksara

[12] Mardiasmo. 2004. Akuntansi Sektor Publik (Edisi Kedua). Yogyakarta:

[13] Mardiasmo. 2004. Otonomi dan Manajemen Keuangan Daerah, ANDI, Yogyakarta.

[14] Paterson, William \& Harahap, Gandhi. 2010. Indonesia Infrastructure Initiative, Perencanaan Pengeluaran dan Penganggaran Berbasis Kinerja (Pbk) pada Direktorat Jenderal Bina Marga, Australia Indonesia Partnership

[15] Robbins, Stephen. 1990. Perilaku Organisasi, Jakarta : Prehalindo.

[16] Robinson, Marc and D. Last. 2009. A Basic Model of Performance-Based Budgeting. Technical Notes and Manuals. International Monetary Fund. Washington.

[17] Sugiyono. 2006. Statistika Untuk Penelitian, Alfabeta, Bandung.

[18] Undang-Undang Nomor 32 Tahun 2004 tentang Pemerintah Pusat dan Daerah.

[19] Young, Richard D. (2003). Performance Based Budget Systems. Public Policy \& Practice, Institute for public service and policy research.

[20] Peraturan Pemerintah Republik Indonesia Nomor 105 Tahun 2000 tentang Pengelolaan dan Pertanggung jawaban Keuangan Daerah.

[21] Peraturan Menteri Dalam Negeri Nomor 58 Tahun 2005 Tentang Pengelolaan Keuangan Daerah.

[22] Peraturan Menteri Dalam Negeri Nomor 13 Tahun 2006 Tentang Pedoman Pengelolaan Keuangan Daerah.

[23] Peraturan Menteri Keuangan, Nomor 93/PMK.02/2011. Tentang Petunjuk Penyusunan dan Penelaahan Rencana Kerja dan Anggaran Kementerian Negara/Lembaga. 